\title{
Health-promoting value of cow, sheep and goat milk and yogurts
}

\author{
Beata Paszczyk*, Elżbieta Tońska, Joanna Łuczyńska
}

\author{
University of Warmia and Mazury in Olsztyn, Chair of Commodity Science and Food \\ Analysis, ul. Michała Oczapowskiego 2, 10-719 Olsztyn, Poland \\ *Corresponding author: Tel.: + 4889523 3681; E-mail: paszczyk@uwm.edu.pl
}

\section{Abstract}

The purpose of the presented study was to determine the fatty acid composition, health lipid indices content and selected micro and macronutrients in cow, sheep and goat milk and yogurts produced there of. Fatty acid composition was determined by the GC-FID method using a 100-m capillary column with CP Sil 88 phase. Microelements (iron, zinc, copper and manganese) and macroelements (magnesium and calcium) were analysed using flame atomic absorption spectrometry, whereas sodium and potassium were determined by the emission method. Phosphorus was analysed by the colorimetric method. The conducted study demonstrated that sheep, cow and goat milks and yogurts were characterized by different contents of fatty acids, micro- and macroelements. Sheep milk and yogurts could be regarded as richer sources of polyunsaturated fatty acids (PUFA), (4.41 and $4.35 \%$ of total fatty acids, respectively), n-3 fatty acids ( $1.05 \%$ of total fatty acids). These samples also had lower n6/n3 ratio (1.93 and 1.92, respectively) and the lowest value index of Thrombogenicity (TI) in comparison to the other analyzed milk and yogurt samples. In turn, goat milk and yogurts were characterized by the highest content of short-chain fatty acids (SCFA), (18.07 and $18.17 \%$ of total fatty acids, respectively) the lowest content of saturated fatty acids (SFA), (54.62 and $54.93 \%$, respectively) and the lowest value index of Atherogenicity (AI) (2.79 and 2.84, respectively). Concentrations of all analyzed microand macroelements were significantly $(P<0.05)$ higher in yogurts than in milk samples used for their production. Goat yogurts contained higher concentrations of copper, iron, and potassium compared to sheep and cow yogurts. In turn, sheep yogurts had more zinc, magnesium, calcium, and phosphorus than the other analyzed yogurt samples.

\section{Key words: milk, yogurt, health benefits, fatty acids, minerals}

\section{Introduction}

Over the past few years, there has been a growing interest in functional food, often referred to as "health food", due to health claims attributed to such food. Functional food are food products containing ingredients positively affecting physio- logical processes which take place in the human body and lead to maintenance of optimum health and decreased risk of typical modern day diseases (Grajek et al., 2005). Milk is recognized as an important source of energy, high-quality protein and essential minerals as well as vitamins. The quality of processed milk, which includes the content 
of nutritional ingredients and the possibility of increasing their bioavailability through fermentation, has direct influence on the high nutritional value of fermented milk drinks. In Poland, yogurt is among the most popular dairy products. It is characterized by high nutritional and dietary value. The popularity of yogurt is due to various health claims and therapeutic values (Goetsch et al., 2011; El-Abbadi et al., 2014).

The research on the effect of fatty acids on human health indicates that only few specific fatty acids are responsible for the negative consequences on consumer health (Simopoulos, 2002; Bernard et al., 2018). Diets rich in fatty acids, such as lauric (C12:0), myristic (C14:0) and palmitic acids (C16:0) are highly related to an increased risk of atherosclerosis, obesity and coronary heart diseases (Ulbricht and Southgate, 1991; Haug et al., 2007). The unsaturated fatty acids (UFAs) are usually called 'healthy fats', especially for their impact on the level of cholesterol in blood (Haug et al., 2007; Arnould and Soyeurt, 2009). PUFAs show stronger decreasing effect of the cholesterol content than monounsaturated fatty acids (MUFAs) (Williams, 2000). n-3 PUFA prevent heart disease and improve immune response. Oleic acid (C18:1) and linolenic acid (C18:3) have anticancer and antiatherogenic properties (Williams, 2000; Haug et al., 2007). n-6 PUFA improvs sensitivity to insulin and thus reduces the incidence of type 2 diabetes (Arnould and Soyeurt, 2009). Conjugated linoleic acid cis9trans11 C18:2 (CLA) has health-positive properties including e.g. anticarcinogenic, antiatherosclerotic, antioxidative and anti-inflammatory effects (Akalln and Tokusoglu, 2003; Parodi, 1997, 2003; Aydin, 2005; Park, 2009; Kee et al., 2010). Trans-vaccenic acid, the main trans-C18:1 isomer in milk fat, has anticancer and antiatherosclerotic effects (Lim et al., 2014).

Cow milk is most commonly used to make yogurt, but milk from goats and sheep is also used. Sheep and goat milk is of high nutritional value. The milk of these animals is characterized by a smaller diameter of fat globules than milk of cows and contains more short-chain and polyunsaturated fatty acids (Park et al., 2007). As a result, goat and sheep milk is digested faster than cow milk. Sheep and goat milk and their derivative products can be recommended to people allergic to cow milk (Albenzio et al., 2016). In the assessment of the quality of milk and dairy products, it is important to define the profile of fatty acids and mineral content.

The aim of the study was to determine the fatty acid composition and health lipid indices content and selected micro and macronutrients in cow, sheep and goat milk and yogurts produced of them.

\section{Material and methods}

\section{Experimental material}

Samples of raw cow, sheep and goat milk were obtained from individual farms located in the Warmia and Mazury voivodeship, and were used for yogurt production. The yogurts were produced with the thermostat method according to the following technological scheme: cow, sheep and goat raw milk was heated to the temperature of $45^{\circ} \mathrm{C}$, centrifuged and degassed $\left(80 \mathrm{kPa} ; 60^{\circ} \mathrm{C}\right)$, subjected to HTST pasteurization $\left(72^{\circ} \mathrm{C} / 15 \mathrm{~s}\right.$ ) (pasteurizer ALFA-LAWAL P20-HB, Sweden), and cooled to the temperature of $6^{\circ} \mathrm{C}$. Afterwards, the milk fat content was standardized to $2 \pm 0.1 \%$. The normalized milk was then subjected to two-stage homogenization (18/5 MPa, temperature $65^{\circ} \mathrm{C}$ ) (homogenizer CN003, Spomasz Bełżyce, Poland) and long-term VHT pasteurization $\left(90^{\circ} \mathrm{C} / 5 \mathrm{~min}\right.$ ) (pasteurizer $\mathrm{AL}$ FA-LAWAL P2O-HB, Sweden). After cooling to the temperature of $45^{\circ} \mathrm{C}$, the milks were inoculated with starter culture Chr. Hansen F-DVS YoFlex ${ }^{\oplus}$ Premium 2.0 DVS (Chr. Hansen, Denmark), containing Streptococcus thermophilus and Lactobacillus delbrueckii subsp. bulgaricus. The prepared vaccine (pre-incubated for 2 hours in $45^{\circ} \mathrm{C}$ ) was added in the amount of $1 \mathrm{~mL}$ per 1 litre of milk. The yogurts were transferred into unitary packages and left to ripen in thermostats (Binder GF115 Tuttingen, Germany) at a temperature of $43.5^{\circ} \mathrm{C}$ until they have reached $\mathrm{pH}$ 4.6.

For every milk type two production processes were carried out. Every time, two samples of yogurts from each batch were collected for analyses. All analyses were conducted in two parallel replications. 


\section{Analytical methods.}

\section{Lipid content}

The fat content in milk and yogurts was determined with instrumental method using the MilcoScan apparatus (Foss, Denmark).

\section{Lipid extraction}

The fat of the milk was extracted according to the Roese-Gottlieb's method (PN-EN ISO 1211:2011).

The fat of the yogurts was extracted according to the Folch's method (Christie, 1973).

\section{Preparation of fatty acid methyl esters}

Fatty acid methyl esters were prepared according to the IDF method using a methanolic solution of $\mathrm{KOH}$ (ISO 15884:2002).

\section{Gas chromatography (GC) analysis}

The composition of fatty acids was determined applying the method of gas chromatography with the help of Hewlett Packard 6890 GC System (Műnster, Germany) with a flame ionization detector (FID), in 100 m capillary column (produced by Chrompack, Middelburg, the Netherlands) with CP Sil 88 phase. The column diameter was $0.25 \mathrm{~mm}$, the film was $0.20 \mu \mathrm{m}$ thick. The determinations were carried out in the following conditions: column temperature from $60^{\circ} \mathrm{C}$ (for $1 \mathrm{~min}$ ) to $180^{\circ} \mathrm{C}$, $\Delta \mathrm{t}=5^{\circ} \mathrm{C} / \mathrm{min}$, detector temperature $250^{\circ} \mathrm{C}$, injector temperature $225^{\circ} \mathrm{C}$, carrier gas helium, gas flow $1.5 \mathrm{~mL} / \mathrm{min}$. Sample injection volume was $0.4 \mu \mathrm{L}$ (split: 50:1). Identification of fatty acids was carried out based on the comparison of their retention time with the retention time of methyl esters of fatty acids of reference milk fat (BCR Reference Materials) of CRM 164 symbol. The positional trans isomers of C18:1 were identified using the standards of methyl esters of these isomers (trans6, Supelco and trans9 and trans11. Sigma-Aldrich), whereas the trans isomers of C18:2 acid (cis,trans and trans,cis) were identified with the use of a mixture of standards of C18:2 isomers (Supelco). The cis9trans 11 CLA isomer was identified using a mixture of CLA methyl esters (Sigma-Aldrich). The percentage content of fatty acids was calculated in reference to the total fatty acid composition (\% mass fraction).

The Lipid Quality Indexes were calculated according to the fatty acids composition using the following formulae (Ulbricht and Southgate, 1991; Osmari et al., 2011)

Index of Atherogenicity (Al)

$$
\begin{aligned}
A l= & (C 12: 0+(4 \times C 14: 0)+C 16: 0) / \\
& (n-3 P U F A+n-6 P U F A+M U F A)
\end{aligned}
$$

Index of Thrombogenicity (TI)

$$
\begin{aligned}
\mathrm{TI}= & (\mathrm{C} 14: 0+\mathrm{C} 16: 0+\mathrm{C} 18: 0) / \\
& ((0.5 \times C 18: 1)+(0.5 \times \text { sum of other MUFA }) \\
& +0.5 \times \mathrm{n}-6 \text { PUFA })+(3 \times \mathrm{n}-3 \text { PUFA })+ \\
& \mathrm{n}-3 \text { PUFA / n-6PUFA }))
\end{aligned}
$$

Hypocholesterolaemic/hypercholesterolaemic ratio $(\mathrm{HH})$ was calculated according to Santos-Silva et al., (2002)

$\mathrm{HH}=[($ sum of $\mathrm{C} 18: 1$ cis 9, C18:2 n-6 and (18:3 n-3) /(sum of C14:0 and C16:0)].

Mineral analysis

For the determination of minerals, samples of milk and yogurts were dried at $105^{\circ} \mathrm{C}$ to achieve constant weight. Afterwards, the samples were carbonized and incinerated in $480{ }^{\circ} \mathrm{C}$ in a matter of several hours. After obtaining white ash it was dissolved in $1 \mathrm{M} \mathrm{HNO}_{3}$, (Suprapur-Merck, Darmstadt, Germany) and transferred with deionized water into a volumetric flask of volume $25 \mathrm{~mL}$. The content of copper (Cu - $324.8 \mathrm{~nm}$ ), iron (Fe - $248.3 \mathrm{~nm}$ ), zinc ( $\mathrm{Zn}-213.9 \mathrm{~nm})$, magnesium (Mg - 285.2) and calcium ( $\mathrm{Ca}-422.7 \mathrm{~nm}$ ) was determined with the application of the Flame Atomic Absorption Spectrometry (FAAS) For this purpose iCE 3000 Series atomic absorption spectrometer (Thermo Scientific, USA) equipped with GLITE data station, deuterium background correction and various cathodic lamps was used. Lanthanum chloride $\left(0.5 \% \mathrm{La}^{3+}\right)$ was added to every sample in calcium (Whiteside 
and Miner, 1984). The content of sodium ( $\mathrm{Na}$ $589 \mathrm{~nm}$ ) and potassium (K - $766.5 \mathrm{~nm}$ ) was determined by Atomic Emission Spectrometry (AES) with acetylene - air flame used the same spectrometer, whereas working in emission mode (Whiteside and Miner, 1984).

Phosphorus ( $P$ - $610 \mathrm{~nm}$ ) was determined using colorimetric method with ammonium molybdate(VI), sodium sulphate(IV) and hydroquinone. Spectrophotometer VIS 6000 (KRÜSS - OPTRONIC, Germany) was used for absorbance measurements.

\section{Statistical analysis}

The statistical analysis was carried out using STATISTICA ver.13.1 software. To calculate the significance of differences, the one-way analysis of variance (ANOVA) was used at a significance level of $a=0.05$. Differences between mean values were evaluated with the Duncan's test.

\section{Results and discussion}

Sheep milk was characterized by the highest fat content, reaching $5.0 \%$. In cow milk, the content of fat was $3.8 \%$ and in goat milk - $3.1 \%$. The content of fat in the produced yogurts was around $2.0 \%$ (Table 1). According to literature data (Zunong et al., 2008; Park et al., 2007; Pajor et al., 2009; Hanuš et al., 2016; Kiczorowska et al., 2017), ruminant species and diet has a significant impact on the fatty acid profile of milk fat. Bernard et al. (2018) reported that diets rich in n-3, such as pasture and diets supplemented with plant oilseeds (linseed, rapeseed) have major effects on decreasing saturated fatty acids (SFA) and increasing unsaturated fatty acids (UFA) in milk fat, yielding potential positive effects on human health, compared to indoors diets. The results presented in Table 2 indicate that saturated fatty acids (SFA) were dominant in fat extracted from cow, sheep and goat milks and yogurts. The content of these acids in cow milk fat reached $61.68 \%$ of the total fatty acids. Significantly lower $(P<0.05)$ contents of these acids were found in sheep and goat milk. In all yogurts, the content of SFAs was similar to their content in milks used for yogurt production (Table 2). Considering this group of fatty acids, in both milk fat and fat extracted from the produced yogurts, the highest contents were found of palmitic acid (C16:0) and stearic acid (C18:0). Palmitic acid content in cow milk accounted for $30.97 \%$ of total fatty acids, whereas in cow yogurts - for $31.44 \%$. A significantly lower $(\mathrm{P}<0.05)$ contents of this fatty acid were found in sheep and goat milks and yogurts (Table 1). The highest content of stearic acid was found in sheep milk and sheep yogurts, while cow and goat milk and yogurts were characterized by a significantly lower $(\mathrm{P}<0.05)$ content of this acid (Table 1). Goat milk and goat yogurts had significantly higher $(\mathrm{P}<0.05)$ content of SCFAs than cow and sheep milks and yogurts (Table 2). The content of SCFAs in goat milk and goat yogurts exceeded $18 \%$ of the total fatty acids. In sheep milk and sheep yogurts SCFA content exceeded $14 \%$ and in cow milk and cow yogurts it reached $10.81 \%$ and $10.13 \%$, respectively. Short-chain fatty acids are important to promote human health. They possess specific properties associated to important physiological functions, among them beneficial effect of C4:0 on the intestinal flora, anti-inflammatory activity and as a factor preventing progression of colorectal cancer and mammary cancer (Hanuš et al., 2018; Gómez-Cortés et al., 2018). Among the SCFAs, C10:0 acid was a predominating fatty acid. In goat milk and goat yogurts the content exceeded $10 \%$ of total fatty acids. The content of C10:0 acid in sheep and cow milk and yogurts was significantly lower $(\mathrm{P}<0.05)$. In sheep milk it was $6.92 \%$ and in sheep yogurts $6.89 \%$. In cow milk and cow yogurts, C10:0 content was below $4 \%$ of the total fatty acids (Table 1). The contents of MUFAs in goat and cow milks and yogurts were similar. A significantly lower $(\mathrm{P}<0.05)$ content of these acids was found in sheep milk and sheep yogurts. In all analysed samples of milk and yogurts, oleic acid (C18:1 cis9) was the most dominant acid of the MUFA group (Table 1). This acid is important from a nutritional point of view since it has anti-cancer and anti-atherogenic properties (Hanuš et al., 2018). A significantly higher content $(P<0.05)$ of this acid was found in goat milk and yoghurts than in sheep and cow milk and yoghurts (Table 1).

The study showed that goat milk contained significantly lower $(\mathrm{P}<0.05)$ amounts of PUFAs than cow and sheep milk (Table 2). The highest content of this group of acids, i.e. $4.35 \%$ of total fatty 
acids, was found in sheep yogurts. The contents of PUFAs in cow yogurts and goat yogurts were significantly lower $(\mathrm{P}<0.05)$ and reached $3.22 \%$ and 2.88 $\%$ of total fatty acids, respectively. Sheep milk and sheep yogurts were characterized by a significantly higher $(\mathrm{P}<0.05)$ content of $\mathrm{n}-3$ acids in comparison to goat and cow milks. The content of n-3 PUFAs in yogurts did not differ from that determined in milk used for their production (Table 2). Sheep milk was characterized by significantly higher contents of n-6 PUFAs compared to goat milk. There were no significant differences in contents of these acids in milk and yogurts made from it. Sheep milk and sheep yogurts had a significantly lower ratio of $\mathrm{n}-6 / \mathrm{n}-3$ acids than cow and goat milks and yogurts. Markiewicz-Kęszycka et al. (2013) stated that n-6/n-3 ratio in sheep milk was 2.31, in goat milk - 5.00, and in cow milk - 6.01. According to Pajor et al. (2009) n-6/n-3 ratio in goat milk from indoor feeding was 6.10 and 3.44 in goat milk from grazed feeding. The $n-6 / n-3$ ratios optimal for the overall health are closer to 1:1 or 2:1 (Simopoulos, 2006; Williams et al., 2011). Adequate intakes of both, n- 6 and n-3 fatty acids, are essential for good health and low rates of cardiovascular disease and type 2 diabetes (Holub and Holub, 2004; Willett, 2007; Simopoulos, 2008). Excessive amounts of $n-6$ PUFAs and a very high $n-6 / n-3$ ratio, as is found in today's Western diets, promote the pathogenesis of many diseases, including cardiovascular disease, cancer, and inflammatory and autoimmune diseases, whereas increased levels of n-3 PUFAs (a lower $n-6 / n-3$ ratio), exert suppressive effects. In the secondary prevention of cardiovascular disease, a ratio of 4/1 was associated with a $70 \%$ decrease in total mortality in people. The lower omega-6/ omega-3 ratio in women with breast cancer was associated with decreased risk. A ratio of 2-3/1 suppressed inflammation in patients with rheumatoid arthritis, and a ratio of 5/1 had a beneficial effect on patients with asthma, whereas a ratio of 10/1 had adverse consequences (SimopouIos, 2008). Studies indicate that the optimal ratio may vary with the disease under consideration (de Lorgeril et al., 1994; Russo, 2009; Simopoulos, 2006, 2008). This is consistent with the fact that chronic diseases are multigene and multifactorial. Therefore, it is quite possible that the therapeutic dose of omega-3 fatty acids will depend on the de- gree of severity of the disease resulting from the genetic predisposition.

Study results showed that the analysed milks were characterized by a similar content of conjugated linoleic acid cis9trans11 C18:2 (CLA) (Table 1). The content of this acid in cow and goat yogurts did not differ from its contents determined in fat from respective milks they were made from. In sheep yogurts, the content of CLA was significantly lower $(\mathrm{P}<0.05)$ than in milk. According to literature data, the level of CLA in milk fat depends mainly on the feeding period, but also on lactation period, breed, and individual determinants of animals (Kelsey et al., 2003; Grega et al., 2005; Ellis et al., 2006; Mel'uchová et al., 2008; Tsiplakou et al., 2008; Zunong et al., 2008; Hanuš et al., 2016).

According to Park et al. (2007), the total CLA content in sheep milk fat was in the range from 0.56 to $0.97 \%$ and in goat milk fat from 0.32 to $1.17 \%$. Żegarska et al. (2006) reported that the content of cis9trans 11 C18:2 (CLA) in cow milk was in the range from $1.06 \%$ to $1.76 \%$ in the summer feeding period and from $0.32 \%$ to $0.52 \%$ in the winter feeding period. In turn, Serafeimidou et al. (2012) demonstrated that the CLA content in fullfat cow milk Greek yogurts ranged from $0.24 \%$ to $1.22 \%$, from $0.06 \%$ to $0.76 \%$ in low-fat ones, from $0.20 \%$ to $1.09 \%$ in sheep full-fat milk yogurts, and from $0.04 \%$ to $0.32 \%$ in goat milk yogurts.

The study showed also that the content of desirable hypocholesterolemic fatty acids (DFAs) was the highest in sheep milk and sheep yogurts. Their significantly lower $(P<0.05)$ contents were found in cow and goat milks as well as in cow and goat yogurts (Table 2). Pilarczyk et al. (2015) stated DFAs content at $47.65 \%$ in milk from Holstein-Friesian cows and at $47.70 \%$ in milk from Simmental cows. Data presented in Table 2 shows that goat milk and goat yogurts were characterized by the lowest content of fatty acids with undesired hypercholesterolemic effect (OFA) and it was $45.60 \%$, respectively $45.82 \%$. Significantly higher $(P<0.05)$ contents of OFAs were found in cow milk and cow yogurts (53.67\% and $54.67 \%$, respectively) (Table 2.)

In an attempt to consider the different effects of various fatty acids, Ulbricht and Southgate (1991) proposed two indices that might better characterize the atherogenic and thrombogenic 
TABLE 1. Fatty acid composition of milk fat and fat of produced yogurts (\% of total fatty acids)

\begin{tabular}{|c|c|c|c|c|c|c|c|c|c|c|c|c|}
\hline \multirow[t]{2}{*}{ Fatty acid } & \multicolumn{2}{|l|}{$\begin{array}{l}\text { Cow milk } \\
(n=4)\end{array}$} & \multicolumn{2}{|c|}{$\begin{array}{l}\text { Cow yogurts } \\
(n=8)\end{array}$} & \multicolumn{2}{|c|}{$\begin{array}{l}\text { Sheep milk } \\
(n=4)\end{array}$} & \multicolumn{2}{|c|}{$\begin{array}{l}\text { Sheep yogurts } \\
(n=8)\end{array}$} & \multicolumn{2}{|l|}{$\begin{array}{l}\text { Goat milk } \\
(n=4)\end{array}$} & \multicolumn{2}{|c|}{$\begin{array}{l}\text { Goat yogurts } \\
(n=8)\end{array}$} \\
\hline & $\bar{x}$ & SD & $\bar{x}$ & SD & $\bar{x}$ & SD & $\bar{x}$ & SD & $\bar{x}$ & SD & $\bar{x}$ & SD \\
\hline Fat content (\%) & 3.8 & 0.06 & 1.99 & 0.02 & 5.0 & 0.03 & 2.01 & 0.01 & 3.1 & 0.03 & 2.0 & 0.02 \\
\hline C $4: 0$ & $3.00^{a}$ & 0.20 & $2.65^{b}$ & 0.18 & $3.04^{a}$ & 0.15 & $3.06^{a}$ & 0.19 & $2.22^{c}$ & 0.22 & $2.32^{c}$ & 0.20 \\
\hline C6:O & $2.30^{b, c}$ & 0.08 & $2.16^{c}$ & 0.09 & $2.26^{\mathrm{b}, \mathrm{c}}$ & 0.22 & $2.39^{a, b, c}$ & 0.09 & $2.46^{\mathrm{a}, \mathrm{b}}$ & 0.30 & $2.56^{a}$ & 0.23 \\
\hline C8:0 & $1.58^{\mathrm{b}, \mathrm{d}}$ & 0.03 & $1.47^{b}$ & 0.07 & $2.18^{c, d}$ & 0.09 & $2.22^{\mathrm{c,d}}$ & 0.06 & $2.96^{a}$ & 0.30 & $2.70^{\mathrm{a}, \mathrm{c}}$ & 1.00 \\
\hline C10:0 & $3.93^{c}$ & 0.08 & $3.85^{c}$ & 0.07 & $6.92^{\mathrm{b}}$ & 0.15 & $6.89^{b}$ & 0.17 & $10.44^{\mathrm{a}}$ & 0.59 & $10.59^{a}$ & 0.42 \\
\hline C10:1 & $0.37^{a}$ & 0.01 & $0.35^{\mathrm{a}}$ & 0.01 & $0.16^{\mathrm{d}}$ & 0.02 & $0.16^{d}$ & 0.02 & $0.19^{c}$ & 0.02 & $0.22^{\mathrm{b}}$ & 0.02 \\
\hline C11:0 & $0.14^{a}$ & 0.02 & $0.14^{a}$ & 0.01 & $0.05^{d}$ & 0.01 & $0.05^{d}$ & 0.01 & $0.08^{c}$ & 0.03 & $0.10^{b}$ & 0.02 \\
\hline C12:0 & $4.57^{a}$ & 0.11 & $4.53^{a}$ & 0.05 & $4.00^{b}$ & 0.08 & $3.91^{\mathrm{b}}$ & 0.13 & $4.51^{\mathrm{b}}$ & 0.43 & $4.57^{b}$ & 0.35 \\
\hline C12:1 & $0.02^{b}$ & 0.01 & $0.03^{b}$ & 0.00 & $0.04^{a}$ & 0.01 & $0.04^{\mathrm{a}}$ & 0.01 & $0.02^{b}$ & 0.01 & $0.02^{b}$ & 0.01 \\
\hline C13:0 iso & $0.12^{a}$ & 0.01 & $0.12^{\mathrm{a}}$ & 0.00 & $0.05^{a}$ & 0.01 & $0.06^{a}$ & 0.04 & $0.04^{a}$ & 0.01 & $0.05^{a}$ & 0.01 \\
\hline C13:0 & $0.31^{\mathrm{a}}$ & 0.03 & $0.32^{\mathrm{a}}$ & 0.02 & $0.16^{\mathrm{b}}$ & 0.01 & $0.15^{b}$ & 0.01 & $0.17^{b}$ & 0.02 & $0.17^{b}$ & 0.02 \\
\hline C14:0 iso & $0.10^{b}$ & 0.01 & $0.10^{\mathrm{b}}$ & 0.02 & $0.17^{\mathrm{b}}$ & 0.01 & $0.17^{a}$ & 0.04 & $0.11^{\mathrm{b}}$ & 0.01 & $0.11^{\mathrm{b}}$ & 0.01 \\
\hline C14:0 & $12.85^{\mathrm{a}}$ & 0.22 & $12.96^{\mathrm{a}}$ & 0.21 & $11.56^{\mathrm{b}}$ & 0.22 & $11.43^{b}$ & 0.30 & $10.53^{c}$ & 0.28 & $10.60^{c}$ & 0.37 \\
\hline C15:0 iso & $0.20^{\mathrm{b}}$ & 0.02 & $0.21^{\mathrm{b}}$ & 0.00 & $0.36^{a}$ & 0.03 & $0.35^{\mathrm{a}}$ & 0.02 & $0.20^{b}$ & 0.02 & $0.20^{b}$ & 0.01 \\
\hline C15:0 aiso & $0.46^{b}$ & 0.01 & $0.48^{c}$ & 0.00 & $0.60^{\mathrm{a}}$ & 0.02 & $0.60^{a}$ & 0.01 & $0.34^{c}$ & 0.00 & $0.35^{c}$ & 0.02 \\
\hline C14:1 & $1.22^{\mathrm{a}}$ & 0.04 & $1.25^{\mathrm{a}}$ & 0.07 & $0.16^{b}$ & 0.02 & $0.16^{b}$ & 0.01 & $0.15^{b}$ & 0.02 & $0.15^{b}$ & 0.01 \\
\hline C15:0 & $1.49^{a, b}$ & 0.12 & $1.51^{\mathrm{a}}$ & 0.09 & $1.39^{c}$ & 0.02 & $1.41^{\mathrm{b}, \mathrm{c}}$ & 0.04 & $0.96^{d}$ & 0.04 & $0.97^{d}$ & 0.06 \\
\hline C16:0 iso & $0.24^{a}$ & 0.01 & $0.25^{a}$ & 0.00 & $0.25^{a}$ & 0.17 & $0.24^{a}$ & 0.15 & $0.31^{\mathrm{a}}$ & 0.03 & $0.31^{\mathrm{a}}$ & 0.02 \\
\hline C16:0 & $30.97^{a}$ & 1.01 & $31.44^{\mathrm{a}}$ & 0.67 & $26.67^{b}$ & 0.50 & $26.68^{b}$ & 0.18 & $26.71^{\mathrm{b}}$ & 0.86 & $26.82^{b}$ & 0.29 \\
\hline $\mathrm{C} 17: 0$ iso & $0.40^{\mathrm{b}, \mathrm{c}}$ & 0.18 & $0.50^{\mathrm{a}}$ & 0.00 & $0.29^{d}$ & 0.05 & $0.27^{d}$ & 0.01 & $0.37^{c}$ & 0.07 & $0.47^{\mathrm{a}, \mathrm{b}}$ & 0.01 \\
\hline C17:0 aiso & $1.37^{\mathrm{b}}$ & 0.61 & $1.74^{\mathrm{a}}$ & 0.07 & $0.52^{c}$ & 0.04 & $0.55^{c}$ & 0.02 & $0.46^{c}$ & 0.12 & $0.67^{c}$ & 0.03 \\
\hline C16:1 & $0.85^{a}$ & 0.59 & $0.57^{b}$ & 0.01 & $0.70^{a, b}$ & 0.06 & $0.70^{a, b}$ & 0.02 & $0.66^{a, b}$ & 0.05 & $0.62^{a, b}$ & 0.02 \\
\hline C17:0 & $0.29^{c}$ & 0.19 & $0.19^{c}$ & 0.00 & $0.87^{\mathrm{a}}$ & 0.02 & $0.86^{\mathrm{a}}$ & 0.02 & $0.55^{5}$ & 0.32 & $0.18^{c}$ & 0.01 \\
\hline C17:1 & $0.22^{c}$ & 0.02 & $0.24^{b}$ & 0.01 & $0.25^{b}$ & 0.01 & $0.24^{b}$ & 0.01 & $0.31^{\mathrm{a}}$ & 0.04 & $0.32^{\mathrm{a}}$ & 0.02 \\
\hline C18:0 & $8.01^{c}$ & 0.68 & $7.83^{c}$ & 0.58 & $10.77^{a}$ & 0.25 & $10.74^{\mathrm{a}}$ & 0.36 & $9.02^{\mathrm{b}}$ & 0.26 & 9.11 & 0.30 \\
\hline trans6 - trans9 C18:1 & $0.23^{a}$ & 0.01 & $0.23^{a}$ & 0.01 & $0.23^{a}$ & 0.09 & $0.18^{b}$ & 0.01 & $0.24^{a}$ & 0.02 & $0.25^{\mathrm{a}}$ & 0.02 \\
\hline $\operatorname{trans} 10+\operatorname{trans} 11 \mathrm{C} 18: 1$ & $1.00^{\mathrm{a}}$ & 0.34 & $0.91^{\mathrm{b}}$ & 0.25 & $1.22^{\mathrm{a}}$ & 0.03 & $1.20^{\mathrm{a}}$ & 0.02 & $1.01^{\mathrm{a}}$ & 0.51 & $0.60^{b}$ & 0.23 \\
\hline trans 12 C18:1 & $0.32^{\mathrm{a}}$ & 0.03 & $0.34^{\mathrm{a}}$ & 0.03 & $0.22^{c}$ & 0.01 & $0.23^{c}$ & 0.02 & $0.26^{b}$ & 0.02 & $0.26^{b}$ & 0.01 \\
\hline trans $13+$ trans 14 C18:1 & $0.74^{a}$ & 0.07 & $0.76^{a}$ & 0.05 & $0.53^{b}$ & 0.04 & $0.53^{b}$ & 0.01 & $0.49^{b}$ & 0.01 & $0.52^{b}$ & 0.03 \\
\hline cis9 C18:1 & $17.26^{c}$ & 0.90 & $17.51^{\mathrm{c}}$ & 0.41 & $18.22^{\mathrm{b}}$ & 0.35 & $18.16^{b}$ & 0.28 & $19.78^{\mathrm{a}}$ & 0.29 & $19.74^{\mathrm{a}}$ & 0.25 \\
\hline cis11 C18:1 & $0.93^{a}$ & 0.03 & $0.94^{a}$ & 0.01 & $0.59^{b}$ & 0.01 & $0.61^{b}$ & 0.02 & $0.63^{b}$ & 0.05 & $0.62^{b}$ & 0.04 \\
\hline cis12 C18:1 & $0.39^{\mathrm{a}}$ & 0.03 & $0.41^{\mathrm{a}}$ & 0.03 & $0.26^{c}$ & 0.01 & $0.25^{c}$ & 0.02 & $0.30^{\mathrm{b}}$ & 0.03 & $0.31^{\mathrm{b}}$ & 0.02 \\
\hline cis13 C18:1 & $0.13^{a}$ & 0.01 & $0.12^{a, b}$ & 0.01 & $0.09^{c}$ & 0.01 & $0.09^{c}$ & 0.02 & $0.11^{\mathrm{b}}$ & 0.01 & $0.09^{c}$ & 0.01 \\
\hline trans16 C18:1 & $0.35^{\mathrm{a}}$ & 0.04 & $0.38^{\mathrm{a}}$ & 0.04 & $0.31^{\mathrm{b}}$ & 0.01 & $0.30^{b}$ & 0.01 & $0.25^{c}$ & 0.01 & $0.25^{c}$ & 0.01 \\
\hline C19:0 & $0.05^{\mathrm{a}}$ & 0.02 & $0.06^{a}$ & 0.01 & $0.09^{\mathrm{a}}$ & 0.10 & $0.04^{\mathrm{a}}$ & 0.02 & $0.09^{a}$ & 0.05 & $0.06^{a}$ & 0.04 \\
\hline cis9trans13 C18:2 & $0.26^{a}$ & 0.03 & $0.21^{\mathrm{a}}$ & 0.08 & $0.22^{\mathrm{a}}$ & 0.03 & $0.24^{a}$ & 0.04 & $0.23^{a}$ & 0.03 & $0.24^{\mathrm{a}}$ & 0.02 \\
\hline cis9trans12 C18:2 & $0.35^{a}$ & 0.02 & $0.39^{\mathrm{a}}$ & 0.02 & $0.39^{a}$ & 0.10 & $0.39^{\mathrm{a}}$ & 0.07 & $0.26^{b}$ & 0.02 & $0.24^{b}$ & 0.01 \\
\hline trans11 cis15 C18:2 & $0.11^{c}$ & 0.05 & $0.14^{b}$ & 0.02 & $0.21^{\mathrm{a}}$ & 0.04 & $0.20^{\mathrm{a}}$ & 0.01 & $0.07^{d}$ & 0.01 & $0.08^{\mathrm{c,d}}$ & 0.01 \\
\hline cis9cis12 C18:2 & $1.76^{b}$ & 0.05 & $1.54^{\mathrm{b}, \mathrm{c}}$ & 0.56 & $2.00^{\mathrm{a}}$ & 0.09 & $1.97^{\mathrm{a}}$ & 0.12 & $1.62^{c}$ & 0.06 & $1.61^{c}$ & 0.03 \\
\hline C2O:0 & $0.12^{b}$ & 0.01 & $0.12^{\mathrm{b}}$ & 0.02 & $0.67^{\mathrm{a}}$ & 0.23 & $0.65^{a}$ & 0.21 & $0.18^{\mathrm{b}}$ & 0.00 & $0.18^{\mathrm{b}}$ & 0.01 \\
\hline C2O:1 & $0.09^{a}$ & 0.01 & $0.10^{\mathrm{a}}$ & 0.01 & $0.03^{c}$ & 0.02 & $0.06^{b}$ & 0.01 & $0.07^{b}$ & 0.01 & $0.07^{b}$ & 0.01 \\
\hline cis9cis12cis15 C18:3 & $0.43^{b}$ & 0.05 & $0.41^{\mathrm{b}}$ & 0.06 & $1.05^{\mathrm{a}}$ & 0.19 & $1.05^{\mathrm{a}}$ & 0.19 & $0.24^{c}$ & 0.04 & $0.24^{c}$ & 0.03 \\
\hline cis9trans11 C18:2 (CLA) & $0.50^{\mathrm{a}, \mathrm{b}, \mathrm{c}}$ & 0.03 & $0.53^{\mathrm{a}, \mathrm{b}}$ & 0.02 & $0.51^{\mathrm{a}}$ & 0.04 & $0.49^{\mathrm{b}, \mathrm{c}}$ & 0.03 & $0.49^{\mathrm{b}, \mathrm{c}}$ & 0.03 & $0.48^{c}$ & 0.03 \\
\hline
\end{tabular}


TABLE 2. Sum of fatty acids and nutritional index of cow, sheep and goat milk and yogurts made of cow, sheep and goat milk

\begin{tabular}{|c|c|c|c|c|c|c|c|c|c|c|c|c|}
\hline & \multicolumn{2}{|l|}{$\begin{array}{l}\text { Cow milk } \\
(n=4)\end{array}$} & \multicolumn{2}{|c|}{$\begin{array}{l}\text { Cow yogurts } \\
(\mathrm{n}=8)\end{array}$} & \multicolumn{2}{|c|}{$\begin{array}{l}\text { Sheep milk } \\
(n=4)\end{array}$} & \multicolumn{2}{|c|}{$\begin{array}{l}\text { Sheep yogurts } \\
(n=8)\end{array}$} & \multicolumn{2}{|c|}{$\begin{array}{l}\text { Goat milk } \\
(\mathrm{n}=4)\end{array}$} & \multicolumn{2}{|c|}{$\begin{array}{l}\text { Goat yogurts } \\
(n=8)\end{array}$} \\
\hline & $\overline{\mathbf{x}}$ & SD & $\bar{x}$ & SD & $\bar{x}$ & SD & $\bar{x}$ & SD & $\bar{x}$ & SD & $\bar{x}$ & SD \\
\hline SCFA & $10.81^{c}$ & 0.36 & $10.13^{c}$ & 0.39 & $14.40^{b}$ & 0.60 & $14.56^{b}$ & 0.47 & $18.07^{a}$ & 1.38 & $18.17^{a}$ & 1.53 \\
\hline SFA & $61.68^{\mathrm{a}}$ & 0.80 & $62.51^{a}$ & 0.60 & $58.46^{b}$ & 0.72 & $58.19^{b}$ & 0.24 & $54.62^{c}$ & 0.61 & $54.93^{c}$ & 1.03 \\
\hline MUFA & $24.13^{a}$ & 0.98 & $24.15^{a}$ & 0.45 & $23.00^{b}$ & 0.42 & $22.90^{\mathrm{b}}$ & 0.31 & $24.45^{a}$ & 0.88 & $24.04^{a}$ & 0.54 \\
\hline PUFA & $3.40^{b}$ & 0.05 & $3.22^{\mathrm{b} . \mathrm{c}}$ & 0.55 & $4.41^{\mathrm{a}}$ & 0.37 & $4.35^{\mathrm{a}}$ & 0.30 & $2.90^{c}$ & 0.09 & $2.88^{c}$ & 0.06 \\
\hline$n-3$ & $0.43^{b}$ & 0.05 & $0.41^{b}$ & 0.06 & $1.05^{\mathrm{a}}$ & 0.19 & $1.05^{\mathrm{a}}$ & 0.12 & $0.24^{c}$ & 0.04 & $0.24^{c}$ & 0.00 \\
\hline$n-6$ & $1.76^{\mathrm{a}, \mathrm{b}, \mathrm{c}}$ & 0.05 & $1.54^{\mathrm{a}, \mathrm{b}, \mathrm{c}}$ & 0.13 & $2.00^{\mathrm{a}}$ & 0.09 & $1.97^{\mathrm{a}, \mathrm{c}}$ & 0.12 & $1.62^{\mathrm{b}, \mathrm{c}}$ & 0.06 & $1.43^{c}$ & 0.00 \\
\hline n6/n3 & $4.14^{\mathrm{b}}$ & 0.38 & $4.35^{b}$ & 0.76 & $1.93^{c}$ & 0.28 & $1.92^{c}$ & 0.23 & $6.98^{\mathrm{a}}$ & 0.15 & $6.04^{a}$ & 0.00 \\
\hline UFA & $27.52^{\mathrm{a}}$ & 1.01 & $27.55^{a}$ & 0.51 & $27.40^{a}$ & 0.47 & $27.25^{a}$ & 0.50 & $27.35^{a}$ & 0.85 & $26.40^{a}$ & 0.01 \\
\hline DFA & $35.53^{b}$ & 1.62 & $35.39^{b}$ & 1.07 & $38.17^{a}$ & 0.67 & $37.99^{a}$ & 0.85 & $36.37^{b}$ & 1.12 & $35.51^{b}$ & 0.30 \\
\hline OFA & $53.67^{a}$ & 1.34 & $54.67^{a}$ & 1.11 & $47.69^{b}$ & 0.76 & $47.44^{b}$ & 0.50 & $45.60^{b}$ & 0.36 & $45.82^{b}$ & 0.75 \\
\hline $\mathrm{Al}$ & $3.31^{\mathrm{a}}$ & 0.21 & $3.34^{a}$ & 0.11 & $2.95^{\mathrm{b}}$ & 0.06 & $2.95^{b}$ & 0.11 & $2.79^{c}$ & 0.06 & $2.84^{\mathrm{b}, \mathrm{c}}$ & 0.02 \\
\hline TI & $3.59^{a}$ & 0.19 & $3.63^{a}$ & 0.12 & $3.03^{c}$ & 0.13 & 3.04 & 0.14 & $3.33^{b}$ & 0.08 & $3.37^{b}$ & 0.04 \\
\hline $\mathrm{HH}$ & $0.44^{b}$ & 0.03 & $0.44^{b}$ & 0.02 & $0.56^{c}$ & 0.01 & $0.56^{c}$ & 0.02 & $0.58^{\mathrm{a}}$ & 0.01 & $0.54^{c}$ & 0.01 \\
\hline
\end{tabular}

$\bar{x}$ - mean value, SD - standard deviation; a,b,c - values denoted in rows by different letters indicate statistically significant differences $(P<0.05)$;

SCFA- short-chain fatty acids (C4-C10); SFA - saturated fatty acids; MUFA - monounsaturated fatty acids; PUFA - polyunsaturated fatty acids,

UFA - unsaturated fatty acids (UFA+PUFA), DFA-hypocholesterolemic fatty acids (UFA + C18:0); OFA-hypercholesterolemic fatty acids (SFA - C18:0), Al (Index of Atherogenicity); TI (Index of Thrombogenicity); HH (hypocholesterolaemic / hypercholesterolaemic ratio)

potential of the diet than simple approaches such as the PUFA/SFA ratio. The atherogenic index (AI) and thrombogenic index ( $\mathrm{TI}$ ) take into account the different effects that single FAs might have on the human health and, in particular, on the probability of increasing the incidence of pathogenic phenomena, such as atheroma and/or thrombus formation. Thus, the higher the Al, the more atherogenic dietary components are. The low Al indicates that milk and milk products could provide protection against coronary heart diseases.

In the present study (Table 2 ), the Al value in goat milk was 2.79 , and was significantly lower $(P<0.05)$ than in sheep milk (2.95) and in cow milk (3.31). In the analyzed yogurts, the values of Al were similar to those determined in milk used for their production. TI index value was the lowest in sheep milk and yogurts. Its significantly lower $(\mathrm{P}<0.05)$ values were found in goat and cow milk and yogurts (Table 2.). Different values of Al and TI in sheep, cow and goat milk were given by Markiewicz-Kęszycka et al. (2013). According to research by Kuczyńska et al. (2012) and Pilarczyk et al. (2015), the values of $\mathrm{Al}$ and $\mathrm{TI}$ in cow milk depend on the breed of cows. In turn, Kiczorowska et al. (2017) claim that the $\mathrm{Al}$ and $\mathrm{TI}$ values in cow milk can vary greatly depending on the diet of cows. According to Sinanoglou et al. (2015), the value of the Al and $\mathrm{TI}$ indexes in sheep milk depend on the breed and the period of lactation. Values obtained by these authors for milk of Greek sheep of the breed Karagouniko and Chios were lower than those obtained in our research. Cossignani et al. (2014) reported that the Al value in goat milk was 2.9, in fresh cheese samples was 2.7, and in semi-hard cheese samples was 2.4. For nutritional evaluation of milk fat the ratio hypocholesterolaemic/hypercholesterolaemic fatty acids $(\mathrm{H} / \mathrm{H})$ was calculated. The $\mathrm{H} / \mathrm{H}$ ratio is related to the functional activity of fatty acids in the metabolism of lipoproteins for plasma 
cholesterol transport and to the risk of cardiovascular disease. Higher values of this ratio are desirable (Santos-Silva et al., 2002). In the presented study the lowest values of this ratio were found in cow milk and cow yogurts (0.44). Significantly higher $(\mathrm{P}<0.05) \mathrm{H} / \mathrm{H}$ content was found in sheep and goat milk (0.56 and 0.58, respectively) as well as in yogurts made from them (Table 2). The hypocholesterolaemic/hypercholesterolaemic $(\mathrm{H} / \mathrm{H})$ ratio of raw milk from two sheep breed (Karagouniko and Chios) at three stages of lactation ranged from 0.50 to 0.68 in all samples examined by Sinanoglou et al. (2015). According to Kiczorowska et al. (2017), H/H ratio in cow milk ranged from 0.37 in milk from an intensive cow feeding system to 0.48 in milk from an intensive cow feeding system with supplementation of eubiotic formulations.

Results presented in Table 3 demonstrate various concentrations of macro- and microelements in the analyzed cow, sheep and goat milks and yogurts. According to literature data (Park and Chukwu, 1989; Al-Webel, 2008; Zamberlin et al., 2012), the concentrations of minerals in milk may not fluctuate much, they vary depending on the species of animals, breed, diet, individual animal, stage of lactation, and status of udder health. Analyses conducted in our study showed similar levels of copper (Cu) and iron (Fe) in the analysed milk samples (Table 3). In yogurts, concentrations of these elements were significantly $(P<0.05)$ higher than in milks they were made from. The highest concentrations of copper (0.015 mg/100 g) and iron $(0.075 \mathrm{mg} / 100 \mathrm{~g})$ were determined in yogurts manufactured from goat milk. In turn, zinc (Zn) concentration in sheep and goat milks was similar and reached $0.521 \mathrm{mg} / 100 \mathrm{~g}$ and $0.489 \mathrm{mg} / 100 \mathrm{~g}$, respectively (Table 3).

A significantly $(P<0.05)$ lower concentration of Zn $(0.402 \mathrm{mg} / 100 \mathrm{~g})$ was found in cow milk. As reported by Park et al. (2007), Zn concentration reached $0.53 \mathrm{mg} / 100 \mathrm{~g}$ in cow milk, $0.56 \mathrm{mg} / 100$ $\mathrm{g}$ in goat milk, and $0.57 \mathrm{mg} / 100 \mathrm{~g}$ in sheep milk. In turn, in a study conducted by Ceballos et al. (2009) Zn levels in goat and cow milks accounted for 0.528 $\mathrm{mg} / 100 \mathrm{~g}$ milk and $0.463 \mathrm{mg} / 100 \mathrm{~g}$ milk, respectively. Results collated in Table 3 demonstrate that zinc concentration in all analysed yogurts was significantly higher than in milks they were made from. Concentrations of magnesium (Mg) and calcium ( $\mathrm{Ca}$ ) were significantly $(\mathrm{P}<0.05)$ lower in goat and cow milks and yogurts compared to sheep milk and sheep milk yogurts (Table 3). Higher concentrations of calcium and magnesium in sheep milk than in goat and cow milk were also reported by Park et. al. (2007). Furthermore, cow and sheep milks were characterized by similar concentrations of sodium ( $\mathrm{Na}$ ) (Table 3), while in goat milk its concentration was significantly $(\mathrm{P}<0.05)$ lower. In all analysed yogurts, sodium concentration was significantly $(P<0.05)$ higher than in respective milks they were made from (Table 3). Our study demonstrated that the analysed milk samples had significantly $(P<0.05)$ different concentrations of potassium $(\mathrm{K})$ and phosphorus $(\mathrm{P})$. Their concentrations were

TABLE 3. Mineral composition of milk and produced yogurts ( $\mathrm{mg} / 100 \mathrm{~g}$ wet weight)

\begin{tabular}{|c|c|c|c|c|c|c|c|c|c|c|c|c|}
\hline & \multicolumn{2}{|l|}{$\begin{array}{l}\text { Cow milk } \\
(n=4)\end{array}$} & \multicolumn{2}{|c|}{$\begin{array}{l}\text { Cow yogurts } \\
(n=8)\end{array}$} & \multicolumn{2}{|c|}{$\begin{array}{l}\text { Sheep milk } \\
(n=4)\end{array}$} & \multicolumn{2}{|c|}{$\begin{array}{l}\text { Sheep yogurts } \\
(n=8)\end{array}$} & \multicolumn{2}{|c|}{$\begin{array}{l}\text { Goat milk } \\
(n=4)\end{array}$} & \multicolumn{2}{|c|}{$\begin{array}{l}\text { Goat yogurts } \\
(n=8)\end{array}$} \\
\hline & $\overline{\mathrm{x}}$ & SD & $\bar{x}$ & SD & $\overline{\mathrm{x}}$ & SD & $\bar{x}$ & SD & $\bar{x}$ & SD & $\bar{x}$ & SD \\
\hline $\mathrm{Cu}$ & $0.010^{c}$ & 0.001 & $0.012^{b}$ & 0.001 & $0.009^{c}$ & 0,002 & $0.012^{b}$ & 0,001 & $0.009^{c}$ & 0.001 & $0.015^{a}$ & 0.001 \\
\hline $\mathrm{Fe}$ & $0.013^{d}$ & 0.01 & $0.033^{b}$ & 0.012 & $0.016^{d}$ & 0,002 & $0.026^{c}$ & 0,003 & $0.017^{d}$ & 0.001 & $0.075^{a}$ & 0.003 \\
\hline $\mathrm{Zn}$ & $0.402^{d}$ & 0.03 & $0.488^{c}$ & 0.02 & $0.521^{\mathrm{b}, \mathrm{c}}$ & 0,058 & $0.610^{\mathrm{a}}$ & 0,013 & $0.485^{c}$ & 0.09 & $0.586^{a, b}$ & 0.08 \\
\hline $\mathrm{Mg}$ & $8.96^{f}$ & 0.24 & $12.84^{d}$ & 0.69 & $16.39^{b}$ & 0.54 & $19.69^{a}$ & 0.89 & $10.43^{e}$ & 0.39 & $15.03^{c}$ & 0.23 \\
\hline $\mathrm{Ca}$ & $134.83^{e}$ & 1.74 & $188.71^{c}$ & 5.03 & $185.50^{c}$ & 3.46 & $235.21^{a}$ & 8.38 & $153.66^{d}$ & 9.66 & $217.85^{b}$ & 13.70 \\
\hline $\mathrm{Na}$ & $29.533^{c}$ & 0.86 & $42.53^{a}$ & 0.54 & $29.23^{c}$ & 2.97 & $41.04^{a}$ & 0.83 & $23.46^{d}$ & 0.77 & $37.50^{\mathrm{b}}$ & 0.58 \\
\hline$K$ & $149.88^{\mathrm{e}}$ & 3.26 & $209.49^{b}$ & 1.90 & $140.73^{f}$ & 11.47 & $194.41^{c}$ & 2.32 & $179.70^{d}$ & 4.70 & $248.62^{a}$ & 8.76 \\
\hline$P$ & $107.13^{d}$ & 5.75 & $143.11^{c}$ & 5.57 & $155.37^{b}$ & 9.14 & $186.81^{a}$ & 18.15 & $116.88^{d}$ & 11.06 & $156.62^{b}$ & 6.35 \\
\hline
\end{tabular}


significantly higher in yogurt samples than in milk samples. The best source of potassium turned were goat yogurts ( $248.62 \mathrm{mg} / 100 \mathrm{~g}$ ), while its concentrations in cow and sheep yogurts reached 209.49 mg/100 g and $194.41 \mathrm{mg} / 100 \mathrm{~g}$, respectively. In turn, sheep yogurts had the highest concentration of phosphorus (186.8 mg/100 g).

\section{Conclusions}

The conducted study demonstrated that sheep, cow, and goat milks and yogurts were characterized by various contents of fatty acids as well as micro- and macroelements.

Sheep milk and yogurts turned out to be richer sources of PUFAs, n-3 fatty acids, had a lower n6/ $\mathrm{n} 3$ ratio and the lowest $\mathrm{TI}$ index value, compared to the other analysed milk and yogurt samples. In turn, goat milk and yogurts were characterized by the highest content of SCFAs, the lowest content of SFAs, and the lowest Al index value.
Concentrations of all analysed micro- and macroelements were significantly $(\mathrm{P}<0.05)$ higher in yogurts than in milk used for their production. Goat yogurts turned out to be better sources of copper, iron, and potassium compared to sheep and cow yogurts. In turn, sheep yogurts had more zinc, magnesium, calcium, and phosphorus than the other analysed yogurt samples.

Results of this study allow concluding that sheep, cow and goat milks and yogurts are characterized by various health-promoting values and therefore their inclusion into a diet is recommended.

\section{Acknowledgements}

The study was financed by the Statutory Theme No. 17.610.008-300. We would like to express special thanks to Waldemar Brandt from the Department of Dairy Science and Quality Management for help in preparing yogurts for research.

\section{Zdravstvena vrijednost kravljeg, ovčjeg i kozjeg mlijeka i jogurta}

\section{Sažetak}

Svrha ovog rada bila je odrediti sastav masnih kiselina te lipida s povoljnim zdravstvenim učincima kao i odabranih mikro- i makroelemenata u kravljem, ovčjem i kozjem mlijeku i jogurtu. Sastav masnih kiselina određivan je GC-FID metodom pomoću 100-m kapilarne kolone s CP Sil 88 fazom. Makroelementi (željezo, cink, bakar i mangan) i mikroelementi (magnezij i kalcij) određivani su primjenom plamene atomske apsorpcijske spektrometrije, dok su natrij i kalij određivani emisijskom metodom. Udio fosfora određen je kolorimetrijskom metodom. Ovo istraživanje pokazalo je da ovčje, kravlje i kozje mlijeko te jogurti sadrže različite količine masnih kiselina, mikro- i makroelemenata. Ovčje mlijeko i jogurt su se pokazali boljim izvorom višestruko nezasićenih masnih kiselina (PUFA) (4,41 odnosno 4,35 \% ukupnih masnih kiselina) i n-3 masnih kiselina (1,05 \% ukupnih masnih kiselina). U usporedbi s ostalim uzorcima mlijeka i jogurta, ovi uzorci također su imali manji omjer n6/n3 masnih kiselina (1,93, odnosno 1,92 ) kao i najniži indeks trombogenosti (TI). S druge strane kozje mlijeko i jogurt sadržavali su najviše koncentracije kratkolančanih masnih kiselina (SCFA), (18,07 odnosno 18,17 \% ukupnih masnih kiselina), najniže koncentracije zasićenih masnih kiselina (SFA), (54,62 odnosno 54,93 \%, ukupnih masnih kiselina) i najniži indeks aterogenosti (Al) (2,79 odnosno 2,84). Koncentracije svih određivanih mikro- i makroelemenata bile su značajno $(P<0,05)$ više u jogurtu nego u mlijeku. Kozji jogurt sadržavao je više koncentracije bakra, željeza i kalija u odnosu na ovčji i kravlji jogurt. S druge strane, ovčji jogurt je sadržavao više cinka, magnezija, kalcija i fosfora u odnosu na ostale vrste analiziranih jogurta.

\section{Ključne riječi: mlijeko, jogurt, zdravstvena vrijednost, masne kiseline, mineralne tvari}


1. Akalln, A.S., Tokusoglu, Ö. (2003): A potential Anticarcinogenic Agent: Conjugated linoleic acid (CLA). Pakistan Journal of Nutrition 2 (2), 109-110. https://doi.org/10.3923/pjn.2003.109.110

2. Albenzio, M., Santillo, A., Avando, M., Nudda, A., Chesse, S., Pirisi, A., Banni, S. (2016): Nutritional properties of small ruminant food products and their role on human health. Small Ruminant Research 136, 3-12. https://doi.org/10.1016/j.smallrumres.2015.12.016

3. Al-Wabel, N.A. (2008): Mineral contents of milk of cattle camels, goats and sheep in the central region of Saudi Arabia. Asian Journal of Biochemistry 3, 373-375. https://doi.org/10.3923/ajb.2008.373.375

4. Arnould, V.M-R., Soyeurt, H. (2009): Genetic variability of milk fatty acids. Journal of Applied Genetics 50, 29-39. https://doi.org/10.1007/bf03195649

5. Aydin, R. (2005): Conjugated linoleic acid: structure, sources and biological properties. Turkish Journal of Veterinary and Animal Sciences 29, 189-195.

6. Bernard, L., Bonnet, M., Delavaud, C., Delosiére, M., Ferlay, A., Fougére, H., Graulet, B. (2018): Milk fat globule in ruminant: Major and minor compounds, nutritional regulation and differences among species. European Journal of Lipids Science and Technology 102, 1-27. https://doi.org/10.1002/ejlt.201700039

7. Ceballos, L. S., Morales, E. R., de la Torre Adarve, G., Castro, J. D., Martinez, L. P., Sampelayo, L. S. (2009): Composition of goat and cow milk produced under similar conditions and analyzed by identical methods. Journal of Food Composition and Analysis 22 (4), 322-329. https://doi.org/10.1016/j.jfca.2008.10.020

8. Christie, W.W. (1973): Lipid analysis. Isolation, separation, identification and structural analysis of lipids. Pergamon Press, Oxford: 39-40.

9. Cossignani, L., Giua, L., Urbani, E., Simonetti, M.S., Blasi, F. (2014): Fatty acid composition and CLA content in goat milk and cheese samples from Umbrian market. European Food Research Technology Published online: 12 July 2014. https://doi.org/10.1007/s00217-014-2287-8

10. de Lorgeril, M., Renaud, S., Mamelle, N., Salen, P., Martin, J.L., Monjaud, I., Mamelle, N., Martin, J.L., Guidollet, J., Touboul, P., Delaye, J. (1994): Mediterranean alpha-linolenic acid-rich diet in secondary prevention of coronary heart disease. The Lancet 343, 1454-1459. https://doi.org/10.1016/s0140-6736(94)92580-1

11. El-Abbadi, N,H., Dao, M,C., Meydani, S.N. (2014): Yogurt: role in healthy and active aging. The American Journal of Clinical Nutrition 99(suppl), 1263S-1270S. https://doi.org/10.3945/ajcn.113.073957

12. Ellis, K.A., Innocent, G., Grove-White, D., Cripps, P., McLean, W.G., Howard, C.V., Mihm, M. (2006): Comparing the fatty acid composition of organic and conventional milk. Journal of Dairy Sciences 89, 1938-1950. https://doi.org/10.3168/jds.s0022-0302(06)72261-5

13. Goetsch, A.L., Zeng, S.S., Gipson, T.A. (2011): Factors affecting goat milk production and quality. Small Ruminant Research 101, 55-63. https://doi.org/10.1016/j.smallrumres.2011.09.025
14. Gómez-Cortés, P., Juárez, M., Angel de la Fuente, M. (2018): Milk fat acids and potential health benefits: An update vision. Trends in Food Science \& Technology 81, 1-9. https://doi.org/10.1016/j.tifs.2018.08.014

15. Grajek, W., Olejnik, A., Sip, A. (2005): Probiotics, prebiotics and antioxidants as functional foods. Acta Biochemical Polonica 52 (3), 665-671.

16. Grega, T., Sady, M., Najgebauer, D., Domagała, J., Pustkowiak, H., Faber, B. (2005): Factors affecting the level of conjugated linoleic acid (CLA) in milk from different cow's breds. Biotechnology in Animal Husbandry 21(5-6), 241-244. https://doi.org/10.2298/bah0502241g

17. Hanuš, O., Krížová, L., Samková, E., Špička, J., Kučera, J., Klimešová, M., Roubal, P., Jedelská R. (2016): The effect of cattle bread, season and type of diet on the fatty acid profile of raw milk. Archives Animal Breeding 59, 373-380. https://doi.org/10.5194/aab-59-373-2016

18. Hanuš, O., Samková, E., Krížová, L., Hasoňová, L., Kala, R. (2018): Role of fatty acids in milk fat and the influence of selected factors on their variability - A Review. Molecules 23, 1-32. https://doi.org/10.3390/molecules23071636

19. Haug, A., Hostmark, A.T., Harstad, O.M. (2007): Bovine milk in human nutrition: a review. Lipids in Health and Disease 6, 25. https://doi.org/10.1186/1476-511x-6-25

20. Holub, D.J., Holub, B.J. (2004): Omega-3 fatty acids from fish oils and cardiovascular disease. Molecular and Cellular Biochemistry 263, 217-225. https://doi.org/10.1023/b:mcbi.0000041863.11248.8d

21. ISO 15884:2002 (IDF 182:2002). Milkfat: Preparation of fatty acid methyl esters.

22. Kee, J-I., Ganesan, P., Kwak, H-S. (2010): Bioactive conjugated linoleic acid (CLA) in milk. Korean Journal for Food Science of Animal Resources 30, 6, 879-885. https://doi.org/10.5851/kosfa.2010.30.6.879

23. Kelsey, J.A., Corl, B.A., Collier, R.J., Bauman, D.E. (2003): The effect of breed, parity, and stage of lactation on conjugated linoleic acid (CLA) in milk fat from dairy cows. Journal of Dairy Sciences 86, 2588-2597. https://doi.org/10.3168/jds.s0022-0302(03)73854-5

24. Kiczorowska, B., Samolińska, W., Marczuk, J., WiniarskaMiczan, A., Klebaniuk, R., Kowalczuk-Vasilev, E., Kiczorowski, P., Zasadna, Z. (2017): Comparative effects of organic, traditional, and intensive production with probiotics on the fatty acid profile of cow's milk. Journal of Food Composition and Analysis 63, 157-163. https://doi.org/10.1016/j.jfca.2017.08.002

25. Kuczyńska, B., Puppel, K., Gołębiewski, M., Kordyasz, M., Grodzki, H., Brzozowski, P. (2012): Comparison of fat and proteins fractions of milk constituents in Montbeliarde and Polish Holstein-Friesian cows from one farm in Poland. Acta Veterinaria Brno 81, 139-144. https://doi.org/10.2754/avb201281020139

26. Lim, J-N., Oh, J- J., Wang, T., Lee, J-S., Kim, S-H., Kim, Y-H., Lee, H-G. (2014): trans-11 18:1 vaccenic acid (TVA) has a direct anti-carcinogenic effect on MCF-7 human mammary adenocarcinoma cells. Nutrients 6, 627-636. https://doi.org/10.3390/nu6020627 
27. Markiewicz-Kęszycka, M., Czyżak-Runowska, G., Lipińska, P., Wójtowski, J. (2013): Fatty acids of milk - A review. Bulletin of the Veterinary Institute in Pulawy 57, 135-139. https://doi.org/10.2478/bvip-2013-0026

28. Mel'uchová, B., Blaško, J., Kubinec, R., Górová, R., Dubravská, J., Margetin, M., Soják, L. (2008): Seasonal variations in fatty acid composition of pasture forage plants and CLA content in ewe milk fat. Small Ruminant Research 78, 56-65. https://doi.org/10.1016/j.smallrumres.2008.05.001

29. Osmari, E.K., Cecato, U., Macedo, F.A.F., Souza, N.E. (2011): Nutritional quality indices of milk fat from goats on diets supplemented with different roughages. Small Ruminant Research 98, 128-132. https://doi.org/10.1016/j.smallrumres.2011.03.030

30. Pajor, F., Galló, O., Steiber, O., Tasi, J., Póti, P. (2009): The effect of grazing on the composition of conjugated linoleic acid isomers and other fatty acids of milk and cheese in goats. Journal of Animal and Feed Sciences 18, 429-439. https://doi.org/10.22358/jafs/66418/2009

31. Park, Y. (2009): Conjugated linoleic acid (CLA): Good or bad trans fat? Journal of Food Composition and Analysis 22S, S4-S12. https://doi.org/10.1016/j.jfca.2008.12.002

32. Park, Y.W., Juárez, M., Ramos, M., Haenlein, G.F.W. (2007): Physico-chemical characteristics of goat and sheep milk. Small Ruminant Research 68, 88-113. https://doi.org/10.1016/j.smallrumres.2006.09.013

33. Park, Y.W., Chukwu, H.I. (1989). Trace mineral concentrations in goat milk from French-Alpine and Anglo-Nubian breeds during the first 5 months of lactation. Journal of Food Composition and Analysis 2, 161-169. https://doi.org/10.1016/0889-1575(89)90077-x

34. Parodi, P.W. (2003): Anti-cancer agents in milkfat. Australian Journal of Dairy Technology 58(2), 114-118.

35. Parodi, P.W. (1997): Cow's milk fat components as potential anticarcinogenic agents. Journal of Nutrition 1055-1059.

36. Pilarczyk, R., Wójcik, J., Sablik, P., Czerniak, P. (2015): Fatty acid profile and health lipid indices in the raw milk of Simmental and Holstein-Fresian cows from on organic farm. South African Journal of Animal Science 45 (1), 30-38. https://doi.org/10.4314/sajas.v45i1.4

37. PN-EN ISO 1211:2011, Milk- Determination of fat content - Gravimetric method (Reference method).

38. Russo, G.L. (2009): Dietary n-6 and n-3 polyunsaturated fatty acids: From biochemistry to clinical implications in cardiovascular prevention. Biochemical Pharmacology 77, 937-946. https://doi.org/10.1016/j.bcp.2008.10.020

39. Santos-Silva, J., Bessa, R.J.B., Santos-Silva F. (2002): Effect of genotype, feeding system and slaughter weight on the quality of light lambs II. Fatty acid composition of meat. Livestock Production Science 77, 187-194. https://doi.org/10.1016/s0301-6226(02)00059-3

40. Serafeimidou, A., Zlatanos, S., Laskaridis, K., Sagredos, A. (2012): Chemical characteristics, fatty acid composition and conjugated linoleic acid (CLA) content of traditional Greek yogurts. Food Chemistry 134, 1839-1846. https://doi.org/10.1016/j.foodchem.2012.03.102
41. Simopoulos, A.P. (2002): The importance of the ratio of omega-6/omega-3 essential fatty acids. Biomedicine \& Pharmacotherapy 56, 365-379. https://doi.org/10.1016/s0753-3322(02)00253-6

42. Simopoulos, A.P. (2006): Evolutionary aspects of diet, the omega-6/omega-3 ratio and genetic variation: nutritional implications for chronic diseases. Biomedicine \& Pharmacotherapy 60, 502-507. https://doi.org/10.1016/j.biopha.2006.07.080

43. Simopoulos, A.P. (2008): The importance of the omega-6/ omega-3 fatty acid ratio in cardiovascular disease and other chronic diseases. Experymental Biology and Medicine 674-688. https://doi.org/10.3181/0711-mr-311

44. Sinanoglou, V. J., Koutsouli, P., Fotakis, Ch., Sotiropoulou, G., Cavouras, D., Bizelis, I. (2015): Assessment of lactation stage and breed effect on sheep milk fatty acid profile and lipid quality indices. Dairy Science and Technology 95, 509-531. https://doi.org/10.1007/s13594-015-0234-5

45. Tsiplakou, E., Kominakis, A., Zervas, G. (2008): The interaction between breed and diet on CLA and fatty acids content of milk fat of four sheep breeds kept indoors or at grass. Small Ruminant Research 74, 179-187. https://doi.org/10.1016/j.smallrumres.2007.06.008

46. Ulbricht, T., Southgate, D. (1991): Coronary heart disease: Seven dietary factors. Lancet 338, 985-992. https://doi.org/10.1016/0140-6736(91)91846-m

47. Willett, W.C. (2007): The role of dietary n-6 fatty acids in the prevention of cardiovascular disease. Journal of Cardiovascular Medicine 8, S42-S45. https://doi.org/10.2459/01.jcm.0000289275.72556.13

48. Whiteside, P., Miner, B. (1984): Pye Unicam Atomic Absorption Data Book. Pye Unicam LTD. Cambridge, England. https://doi.org/10.1021/ac00277a778

49. Williams, C.M. (2000): Dietary fatty acids and human health. Annales De Zootechnie 49, 165-180. https://doi.org/10.1051/animres:2000116

50. Williams, Ch. D., Whitley, B.M., Hoyo, C., Grant, D. J., Iraggi, J. D., Newman, K. A., Gerber, L., Taylor, L.A., McKeever, M.G., Freedland, S.J. (2011): A high ratio of dietary n-6/n-3 polyunsaturated fatty acids is associated with increased risk of prostate cancer. Nutrition Research 31, 1-8. https://doi.org/10.1016/j.nutres.2011.01.002

51. Zamberlin, Š, Antunac, N., Havranek, J., Samaržija, D. (2012): Mineral elements in milk and dairy products. Mljekarstwo 62 (2), 111-125.

52. Żegarska, Z., Paszczyk, B., Rafałowski, R., Borejszo, Z. (2006): Annual changes in the content of unsaturated fatty acids with 18 carbon atoms, including cis9trans 11 C18:2 (CLA) acid, in milk fat. Polish Journal of Food and Nutrition Sciences 15/56 (4), 409-414. https://doi.org/10.17221/3386-cjfs

53. Zunong, M., Hanada, M., Aibibula, Y., Okamato, M., Tanaka, K. (2008): Variations in conjugated linoleic acid concentrations in cow's milk, depending on feeding systems in different seasons. Asian-Australasian Journal of Animal Sciences 21, 10, 1466-1472. https://doi.org/10.5713/ajas.2008.80148 